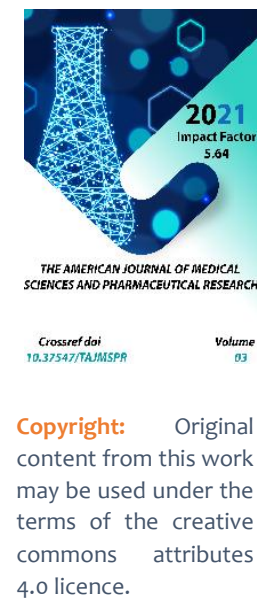

\title{
Modern Scientific Research In Oncological Diseases
}

Parpieva Odinakhon Rakhmanovna

Senior Teacher, Fergana State University, Uzbekistan

Ostanaqulov Alijon Dadajon Ugli

Master Student, Fergana State University, Uzbekistan

Copyright: Original

content from this work

4.0 licence.

\section{ABSTRACT}

The flow of information all over the world, the process of globulation, the rush of individual relations do not transfer its influence on the human psyche. As a result of external factors provoking negative changes in the human psyche, emotional exposure, tension, in general, a violation of the normative indicator of the state of health, psychosomatic disorder arises.

The role of human psychics in the origin, course and treatment of cancer as a result of the achievements of science, the integration of science has been reflected in the research carried out in the second half of the 2oth century.

\section{KEYWORDS}

Oncological disease, psycho-therapeutic effect, psycho-oncology, carcinogenesis, cognitive disorders, negative energy, energy body, genesis, emotional state, adequate attitude, psychotopia, mental factors, psychological help, stress, psychocorrection program.

\section{INTRODUCTION}

Oncological diseases are one of the pressing medical and social problems that are seriously affecting human health in the whole world today. According to the World Health Organization, the indicator of the incidence of such diseases is growing from year to year. 
Every year in the world, about 16 million people are diagnosed with primary cancer. In particular, in Uzbekistan, more than 100 thousand patients are on the account of oncological diseases. In oncological diseases occupy the leading place in the cancer of the mammary gland, the next places are diseases of the stomach, cervix and lung cancer. Unfortunately, in more than 50 percent of cases, these diseases are detected in those cases when full-fledged treatment is difficult in the evening, that is, in the third and fourth stages. Therefore, the construction against this medical and social problem is a huge responsibility not only to the health sector, but also to the society as a whole.

It is well known that today breast cancer has become a serious concern of the world community, causing the untimely death of many women. Alas, this disease is getting younger from year to year, if its hooks were observed among women aged 50-60 years, today its first complications are observed in teenage girls, even in children, newborns. And the fact that the reason for its origin and the alleged measures are not clear, requires the fight against it in due time.

In developed countries, every fourth person is at risk of getting cancer, every fifth person dies from it. Modern statistics on cancer show that every year about 10 million people around the world suffer from this disease. According to the World Health Organization, the growth of oncological diseases has increased by $10 \%$ in the last 15 years.

As a result of external factors provoking negative changes in the human psyche, emotional exposure, tension, in general, a violation of the normative indicator of the state of Health, psychosomatic disorder arises.
Today, it has been proven that in the study of somatic diseases cannot necessarily cure the disease without taking into account the psychic factors. Oncological diseases, which in recent years have become known as diseases of the XXI century, have a rate of growth all over the world.

In the World Health System, psychotic effects on diseases have been recognized as one of the effective methods of treatment.

The role of human psychics in the origin, course and treatment of cancer as a result of the achievements of Science, the integration of science has been reflected in the research carried out in the second half of the 2oth century.

Today, taking measures to treat oncological patients has become a problem not only in the field of medicine, but also in the field of psychology.

Studies on the study of the psychology of oncological patients have caused a new direction in the integration of medical and psychological sciences into the body and it began to be slurry with the term "Psychooncology".

Psychooncology is a branch of clinical practice and science in the unification of the disciplines of psychology, oncology and sociology, established and developed as a separate branch of oncology. The field of psychooncology goes beyond the limits of cancer treatment, it covers the psychological and social aspects of the patient's lifestyle, oncological disease. Psychooncology studies the influence of disease on the psychological health of the patient and the psychological and social effects of medical personnel and members of the patient family in the course of 
carcinogenesis and oncological process. It also reviews the effects of cognitive impairment and plasebo and nosebo on the body as a result of light therapy and chemical therapy.

In the detection and diagnosis of the disease in most patients, his mental state is neglected, while the human psyche is inextricably linked with health, without which he does not remain exposed to health. In physics, there is a concept of "the influence of spiritual law". This principle states that at first the disease begins to develop in our energetic body, that is, in our psyche. If a person is able to change his lifestyle, mental state on the positive side, improve his quality of life, this can prevent the transition of the disease from physical to the body and preserve health. Intensive negative energy accumulates in our mental body, sooner or later it passes into our physical body and causes the development of various diseases and symptoms. Many experts believe that the genesis of some cancers develops in this way.

Galen, an ancient Roman doctor who lived in the second century, said that women who catch themselves, trigger, in a good mood, less likely to get cancer than women who are depressed. Many qualified doctors, who lived in later periods, also thought so. The French physiologist Dizey Djendron, who lived at the beginning of the eighteenth century, in his observations believed that unfortunate events, grief, depressed mood are one of the leading causes of the development of the disease.

In one of the studies, an American scientist in the field of monitoring the emotional state of cancer, Elida Evans, described in detail the direct psychoanalysis of oncological disease in her book "monitoring cancer from a psychological point of view". About this book there is such a saying of the famous psychologist and Doctor Karl Yung:"The author of the book Mrs Evans managed to solve many mysteries of cancer." After psychooncology in medical science was recognized as the department of Oncology, the sphere began to develop rapidly in the 80 years of the last century. Since 1990 year, two scientific journals have been published in foreign countries under the name of this department. Since 1995, doctors of psychooncology are trained in several world medical institutions.

On the example of the life of a well-known psychologist and doctor Louise Hei showed effective treatment of cancer. At a young age, doctors gave him a diagnosis on the last stage of cancer. At first it seemed that there was no hope of getting rid of this grief and staying alive. But he managed to overcome the severe and incurable patient, putting into force the will he has. In the book "cure yourself yourself", he writes: "as any man knows about cancer in himself, I was also in a panic and laughed. But, I knew that it was possible to overcome the disease through the method of psychotherapy. I was sure that he would suck a person from the inside out of anguish and sadness, and I understood that he would work great hard for himself. I have accumulated my spiritual and mental strength and tried to grow out of grief-it-hares." In this work, the author in detail touched on the application of psychotic methods in medicine.

It is worthwhile to study the stages of psychological change in the course of the disease in order to determine the chances of providing psycho-therapeutic assistance to oncological patients. All diseases bring about changes in the human psyche, but the internal 
psychological picture of oncological diseases is unique.

Cancer can be distinguished not only by the physiological state of the patient, but also by his psychological state from other diseases, we can see the observation of depression, depression, internal discomfort in patients not only from theoretical sources, but also from examples in our lives.

Ibn Sina wrote down her own opinion about the fact that the origin of a number of diseases depends on the nervous system, anger, fear, severe compressions deplore the body and provoke the occurrence of various diseases. He has proven his point of view based on the following experience. Ibn Sina kept one sheep in normal conditions, and the other in a cage, and fed the elixir the same. Around the sheep in the cage, the wolf wandered. After a day or two, the sheep in the cage, which circulates around the Wolf, will eat and die from exhaustion. Ibn Sina concluded that the death of the sheep was caused by mental stress and, as a result, the depletion of the organism.

Ibn Sina writes that" every person is obsessed with a particular client and should definitely pay attention to this when treating a patient." He paid great attention to the mental factors in the development of diseases, understood that the disease is different in each person, and this situation depends on the client of the patient, his family circumstances, what social strata he belongs to and who is treating him.

Providing psychological assistance to patients with oncological disease is an important task in studying the significant aspects of the process of issues. Solution of this task:

1. Expanding the possibility of treatment of oncological patients;
2. Increase the effectiveness of medical treatment measures by triggering the occurrence of human internal reserves;

3. It provides an opportunity to overcome the cases of mental crises that occur as a result of oncogynecological diseases in women who make up a large part of the population.

One of the reasons for the occurrence of oncological diseases is the stresses that occur in human life. In them, as a result of psychological influence on the relaxation of reactions to stress, the patient will be able to cope with the state of frustration and weakness. Providing psycho-therapeutic assistance to oncological patients in the spirit of oncological patients is aimed at eliminating the negative emotional states that arise in the body, forming an adequate attitude to the disease, self, surrounding people, the future, a practical effect is provided through a special psychocorrection program, which has a positive effect on the received treatment procedures. Psychocorrection program is structured on the basis of modern approaches to Psychology, the latest innovations in science, each training is conducted purposefully, systematically, allowing the human psyche to strengthen the internal system, the implementation of the principle of unity of body and soul.

All the measures taken are very important for the preservation of human health, of course. However, the notion that prevention is an advantage rather than a cure for the disease, is more valuable for the field of oncology. Therefore, the prevention of the disease among the population remains a priority task. Today's modern research has proved that as long as it is possible to prevent oncological diseases with the help of simple methods that 
everyone can follow in their daily lives. That is, rational nutrition, being physically active, avoiding harmful habits such as smoking, drinking, maintaining a healthy lifestyle, passing a medical examination at the right time will prevent a person from suffering from such severe diseases.

Therefore, providing psychological assistance to oncological patients, in addition to medical impact, is important.

\section{REFERENCES}

1. Блинов Н.Н, В.А.Чулкова “Роль психоонкологии В лечении онкологических больных". Вопр. онкол,-— 1996.-№ 5.-С.

2. Давыдов М.И. Психоонкология/М.И.Давыдов//Психич еские расстройства в общей медицине/ под ред.А.Б. Смулевича том 02 №3. 2007.

3. Муродхўжаев Н.К,Худайқулов Т.Қ., жўраев М.Д. Онкология: Тиббиёт институтлари талабалари учун дарслик.Т.: Абу-Али Ибн-Сино, 2002.- 2646

4. Черенков В.Г. Клиническая онкология. 3-е изд. Москва -2010г.

5. В.Ф.Матвеев. Медицина психологияси, этикаси ва деонтологияси. 1991й.

6. З.Ибодуллаев “Тиббиёт психологияси”. -Тошкент. -2008.

7. А.А.Уразбаева “Онкологик беморларга психологик ёрдам кўрсатиш” услубий қўлланма. Тошкент 2017 й. 